\title{
THE ROLE OF IMMUNOSTIMULANTS IN THE PREVENTION OF COLIBACILLOSIS, SALMONELLOSIS AND PASTEURELLOSIS IN CALVES
}

\author{
Navruzov N.I. ${ }^{l}$ \\ ${ }^{1}$ Junior researcher, Veterinary Research Institute, Uzbekistan. \\ B.A.Elmurodov ${ }^{2}$ \\ ${ }^{2}$ Scientific adviser: Doctor of Veterinary Sciences, Senior Research Fellow, \\ Veterinary Research Institute, Uzbekistan.
}

\begin{abstract}
When a natural eco-friendly chitosan solution is used in combination with the GOA formal vaccine used against colibacillosis, salmonellosis and pasteurellosis, the immune system in calves becomes stable.

Keywords: ecology, xitozan, immunostimulant, colibasillosis, vaccine, immunoglobulin, agglutinabilation, salmonellas.
\end{abstract}

\section{INTRODUCTION}

Decree of the President of the Republic of Uzbekistan dated March 28, 2019 №5696 "On measures to radically improve public administration in the veterinary and livestock sector and the implementation of the resolution of March 28, 2019 PQ-4254 on the organization of the State Committee for Veterinary and Livestock Development and June 1, 2017" Resolution of the State Veterinary Committee of the Republic of Uzbekistan No. PP-3026 on measures to organize the activities of the State Veterinary Committee of the Republic of Uzbekistan and Resolution No. PP-4947 of February 7, 2017 "On a new approach to the state and society in the development of the Republic" According to the Law "On Veterinary Medicine" (in the new edition), taking into account the shortage of veterinary drugs in private, subsidiary farms engaged in animal husbandry and the import of veterinary drugs used in animal husbandry, mainly from foreign countries. research focuses on creating competitive biopreparations using local resources. At the expense of various biopreparations produced at VITI, it is possible to save the state currency spent on imports.

Agriculture has a special place in the economy of our country and great importance is attached to the development of this sector. The development and increase of profitability of livestock, which is the main branch of agriculture, depends on factors such as increasing the number of farm animals in recent years, increasing their productivity, obtaining healthy children, proper care, protection from various infectious and non-infectious diseases. Infectious diseases of farm animals, especially infectious diseases in livestock, are considered a major risk. We all know that infectious diseases such as colibacillosis, salmonellosis and pasteurellosis are one of the main problems in animal husbandry, which is common in farm animals, especially among young animals. The lack of biologically active and chemical drugs used in the prevention or treatment of diseases of farm animals in the veterinary field further complicates the problem and contributes to the wider spread of infectious diseases.

\section{RELEVANCE OF THE TOPIC}

Nowadays, the use of natural organic, pure ecological products is important for the people. In agriculture, veterinary medicine, as well as in the field of medicine, pure natural ecological products are of paramount importance. In particular, the enrichment of veterinary drugs with pure natural organic matter increases the natural resistance in animals.

Colibacillosis is an acute infectious disease of young animals, occurring mainly in young animals from 1 to 8 days of age. Typical symptoms of colibacillosis are: enteritis, sepsis and weakness.

Salmonellosis (paratyphoid) is an acute and chronic infectious disease of young animals and poultry, mainly characterized by septicemia, fever, intoxication and gastrointestinal disorders in calves aged 10-60 days.

Pasteurellosis is characterized by acute and chronic hemorrhagic septicemia in mammals, poultry and fur animals, croupous pneumonia, pleurisy, purulent necrotic pneumonia in the lungs, kerato-conjunctivitis, hemorrhagic enteritis.

It is natural that the body's immune system is weakened, leading to respiratory diseases, gastrointestinal, infectious and non-infectious diseases. In particular, this situation increases the economic 
harm of colibacillosis, salmonellosis and pasteurellosis in young calves. Antibiotics used in the treatment of this type of mixed disease have a negative impact on the morphopathological, morpho-functional state of the organism. Although the ecologically pure chitosan drug is widely studied in the plant kingdom, its level of effect on the animal body is one of the current problems. Therefore, in our study, chitosan solution (chitosan succinate $4 \%$ ) was used in the case of mixing GOA formal vaccine against colibacillosis, salmonellosis and pasteurellosis in farm animals.

\section{OBJECT AND METHODS OF RESEARCH}

Our research was conducted in the laboratory of microbiology of VITI, the laboratory of immunology of the diagnostic center "Sangzor" and in large livestock complexes "SIYOB SHAVKAT ORZU". Our results and analysis were conducted on the basis of these data (2012-2018). Enrichment of vaccines against colibacillosis, pasteurellosis and salmonellosis with the natural compound "chitosan" is the main goal of our experiment.

Immunological reactions were carried out on young calves to study the effectiveness of farm animals prepared from strains of type A of E. coli, Salmonella Dublin, P. multocida against pasteurellosis, colibacillosis and salmonellosis by adding a solution of succinate chitosan (4\%) with GOA formal vaccine.

The body's fight against microbes is determined by immunoglobulins. Immunoglobulin $\mathrm{E}$ and immunoglobulin D are almost non-existent in farm animals (F.J. Bourne et al. 1978). IgM are macroglobulins that are formed in the early stages of immune reactions. IgG is the major immunoglobulin in the serum, of which there are two types, IgG1 and IgG2. In addition to immunoglobulins, the main cellular elements of the organism are macrophages (monocytes), as well as vital T and B lymphocytes. Studies were conducted on 8 head of calves available in VITI's laboratories. The results of pre- and post-agglutination reactions and immunological (IgM and ImG) analysis before the introduction of vaccines with "naturally activated" chitosan solution into the body of calves during the study are recorded in the table below.

Group I was an experimental group in which three young calves were injected with a solution of natural organic, environmentally friendly pure chitosan succinate $(4 \%)$ into the GOA formal vaccine against colibacillosis, salmonellosis, and pasteurellosis.

Group II is the experimental group, in which three young calves were injected only with the GOA formal vaccine against colibacillosis.

Group III was the control group, and two head of calves were left under control and no solution was injected into them.

To determine the results of our studies, immunological and agglutination reaction analyzes were obtained from serum obtained from calves in the experimental and control group.

A method for determining the effect of immunostimulants in the prevention of colibacillosis in calves Table 1.

\begin{tabular}{|c|c|c|c|c|c|c|}
\hline \multirow{3}{*}{ Groups } & $\begin{array}{c}\text { Number of } \\
\text { head of } \\
\text { animals }\end{array}$ & $\begin{array}{c}\text { The AR titer } \\
\text { (pre- } \\
\text { experiment) is } \\
\text { normally 1:200 }\end{array}$ & $\begin{array}{c}\text { AR titer } \\
\text { (post- } \\
\text { experiment) }\end{array}$ & $\begin{array}{l}\text { C reactive } \\
\text { protein is } \\
\text { normally } \\
0.1-0.3 \mathrm{mg} \\
/ 1\end{array}$ & $\begin{array}{l}\text { IgM norm } \\
\text { is 0.4-2.3 } \\
\mathrm{mg} / 1\end{array}$ & $\begin{array}{l}\text { IgG norm } 7 \\
-16 \mathrm{mg} / 1\end{array}$ \\
\hline $\begin{array}{c}\text { I group } \\
\text { experience }\end{array}$ & 1 & $1: 200$ & $1: 1600$ & 0,42 & 2,9 & 20 \\
\cline { 2 - 7 } & 2 & $1: 100$ & $1: 800$ & 0,34 & 2,7 & 16 \\
\hline \multirow{2}{*}{$\begin{array}{c}\text { Group II } \\
\text { experiment }\end{array}$} & 3 & $1: 200$ & $1: 800$ & 0,4 & 2,8 & 18 \\
\cline { 2 - 7 } & 5 & $1: 200$ & $1: 800$ & 0,3 & 2 & 17 \\
\hline Control & 6 & $1: 200$ & $1: 800$ & 0,32 & 2,4 & 16 \\
\cline { 2 - 7 } group & 7 & $1: 200$ & $1: 400$ & 0,3 & 2,2 & 17 \\
\hline
\end{tabular}

A method for determining the effect of immunostimulants in the prevention of calf salmonellosis

Table 2.

\begin{tabular}{|c|c|c|c|c|c|c|}
\hline \multirow{3}{*}{ Groups } & $\begin{array}{c}\text { Number of } \\
\text { head of } \\
\text { animals }\end{array}$ & $\begin{array}{c}\text { The AR titer } \\
\text { (pre- } \\
\text { experiment) is } \\
\text { normally 1: } \\
\text { Inte }\end{array}$ & $\begin{array}{c}\text { The AR titer } \\
\text { (pre- } \\
\text { experiment) } \\
\text { is normally } \\
1: 200\end{array}$ & $\begin{array}{c}\text { The AR titer } \\
\text { (pre- } \\
\text { experiment) } \\
\text { is normally } \\
1: 200\end{array}$ & $\begin{array}{c}\text { The AR titer } \\
\text { (pre- } \\
\text { experiment) } \\
\text { is normally } \\
1: 200\end{array}$ & $\begin{array}{c}\text { The AR titer } \\
\text { (pre- } \\
\text { experiment) } \\
\text { is normally } \\
1: 200\end{array}$ \\
\hline $\begin{array}{c}\text { I group } \\
\text { experience }\end{array}$ & 1 & $1: 200$ & $1: 1600$ & 0,42 & 3,5 & 20 \\
\cline { 2 - 7 } & 2 & $1: 100$ & $1: 800$ & 0,34 & 2,7 & 22 \\
\hline
\end{tabular}




\begin{tabular}{|c|c|c|c|c|c|c|}
\hline \multirow{3}{*}{$\begin{array}{c}\text { Group II } \\
\text { experiment }\end{array}$} & 4 & $1: 200$ & $1: 800$ & 0,3 & 2,6 & 17 \\
\cline { 2 - 7 } & 5 & $1: 200$ & $1: 800$ & 0,33 & 2,4 & 18 \\
\cline { 2 - 7 } & 6 & $1: 200$ & $1: 800$ & 0,35 & 2,5 & 18 \\
\hline \multirow{2}{*}{$\begin{array}{c}\text { Control } \\
\text { group }\end{array}$} & 7 & $1: 100$ & $1: 100$ & 0,2 & 0,8 & 9 \\
\cline { 2 - 7 } & 8 & $1: 50$ & $1: 50$ & 0,21 & 0,9 & 8 \\
\hline
\end{tabular}

A method for determining the effect of immunostimulants in the prevention of pasteurellosis in calves

\begin{tabular}{|c|c|c|c|c|c|c|}
\hline \multirow{3}{*}{ Groups } & $\begin{array}{c}\text { Number of } \\
\text { head of } \\
\text { animals }\end{array}$ & $\begin{array}{c}\text { The AR titer } \\
\text { (pre- } \\
\text { experiment) is } \\
\text { normally 1: } 200\end{array}$ & $\begin{array}{c}\text { The AR } \\
\text { titer (pre- } \\
\text { experiment) } \\
\text { is normally } \\
1: 200\end{array}$ & $\begin{array}{c}\text { The AR } \\
\text { titer (pre- } \\
\text { experiment) } \\
\text { is normally } \\
1: 200\end{array}$ & $\begin{array}{c}\text { The AR } \\
\text { titer (pre- } \\
\text { experiment) } \\
\text { is normally } \\
1: 200\end{array}$ & $\begin{array}{c}\text { The AR } \\
\text { titer (pre- } \\
\text { experiment) } \\
\text { is normally } \\
1: 200\end{array}$ \\
\hline \multirow{2}{*}{$\begin{array}{c}\text { I group } \\
\text { experience }\end{array}$} & 1 & $1: 200$ & $1: 1600$ & 0,45 & 2,9 & 22 \\
\cline { 2 - 7 } & 2 & $1: 100$ & $1: 1600$ & 0,34 & 2,8 & 19 \\
\hline \multirow{2}{*}{$\begin{array}{c}\text { Group II } \\
\text { experiment }\end{array}$} & 3 & $1: 100$ & $1: 800$ & 0,42 & 2,8 & 20 \\
\cline { 2 - 7 } & 4 & $1: 200$ & $1: 400$ & 0,36 & 2 & 17 \\
\hline \multirow{2}{*}{$\begin{array}{c}\text { Control } \\
\text { group }\end{array}$} & 6 & $1: 200$ & $1: 800$ & 0,32 & 2,4 & 18 \\
\cline { 2 - 7 } & 7 & $1: 100$ & $1: 800$ & 0,35 & 2,2 & 16 \\
\hline
\end{tabular}

As a result of our study, it was found that the average antibody titer to the pathogens of pasteurellosis, colibacillosis and salmonellosis in the calves of the first experimental group was 1: 800, the level of immunoglobulins in the blood was $2.3 \mathrm{mg} / 1$ higher than normal in the first group. In particular, these indicators were found to be high in IgM and IgG in colibacillosis, with higher efficacy than in the second and third groups. In conclusion, studies have shown that GOA in young calves is highly effective when injected into a formal vaccine against colibacillosis, salmonellosis, and pasteurellosis by adding a solution of natural organic, environmentally friendly pure chitosan succinate $(4 \%)$.

\section{CONCLUSION}

The study concluded the following:

-Young calves have a high cost-effectiveness of infection from colibacillosis, salmonellosis and pasteurellosis. -A mixture of GOA formal vaccine against colibacillosis, salmonellosis and pasteurellosis of farm animals, used to prevent colibacillosis, salmonellosis and pasteurellosis it was found that GOA used against colibacillosis, salmonellosis, and pasteurellosis had a higher immune status than the vaccine used against the formal vaccine.

\section{REFERENCES}

[1] Kean T, Roth S, Thanou M (2005). "Trimethylated chitosans as non-viral gene delivery vectors: cytotoxicity and transfixion efficiency". J Control Release 103 (3): 643-53.

[2] «http://sportswiki.ru

[3] Kudryashov A.A. Infectious diseases of animals / A.A. A. Kudryashov. M.: Lan, 2007 .-- 624 art.

[4] Kislenko, VN Veterinary microbiology and immunology. Part 3. Private microbiology / VN Kislenko, NM Kolychev, OS Suvorina. -M. : Kolos S, 2007.215 art.

[5] B.A. Elmurodov, S.H. Abdalimov, I.D. Sheralieva. Diseases of young animals Samarkand 2016. Zarafshan Publishing House. Pages 100-113.

[6] H.S. Salimov. Epizootology Tashkent-2016. 445-451 st.

[7] Irgashevich, D. A. (2020). Development of national network (tas-ix). ACADEMICIA: An International Multidisciplinary Research Journal, 10(5), 144-151. Article http://dx.doi.org/10.5958/2249$\underline{7137.2020 .00254 .2}$ 